Mavi Atlas, 5(2)/2017: 355-382. Araştırma Makalesi | Research Article

Makale Geliş | Received: 15.08.2017

Makale Kabul | Accepted: 02.10.2017

DOI: $10.18795 /$ gumusmaviatlas.351369

Murat YÜKSEL

Yrd. Doç. Dr. | Assist. Prof. Dr. Ordu Üniversitesi, Fen-Edebiyat Fakültesi, Sosyoloji Bölümü, Ordu-Türkiye Ordu University, Faculty of Arts and Sciences, Department of Sociology, Ordu-Turkey orcid.org/0000-0003-4448-4062

bdmurat81@hotmail.com

Murat YEŞiL

Yrd. Doç. Dr. | Assist. Prof. Dr. Ordu Üniversitesi, Ziraat Fakültesi, Peyzaj Mimarlığı Bölümü, Ordu-Türkiye Ordu University, Faculty of Agriculture, Department of Landscape Architecture, Ordu-Turkey orcid.org/0000-0002-3643-5626 muraty25@hotmail.com

\title{
Kent ve Rekreasyon (Ordu Kenti Örneği)*
}

$\ddot{O} \mathbf{z}$

$\mathrm{Bu}$ araştırmanın konusunu, Ordu kentinde yaşayan insanların serbest zamanlarını nasıl ve nerede değerlendirdiği, rekreasyon alanlarını ne sıklıkla kullandığı ve çeşitli rekreasyon alanları hakkındaki görüşleri oluşturmaktadır. Ordu kentinde yaşayanların daha kaliteli bir serbest zamana ve daha çeşitli rekreasyon alanlarına sahip olmalarına yönelik analizler de araştırmanın amacını teşkil etmektedir. Bu kapsamda, rekreasyon alanları ile ilgili görüşler cinsiyet, yaş, eğitim, gelir, meslek, Ordulu olma(ma), büyükşehirde yaşama(ma) eksenlerinde değerlendirilmiştir. Araştırma Ordu'nun Altınordu ilçesinde Haziran-Ekim 2015 tarihleri arasında yapılmıştır. Tesadüfi örnekleme tekniği ile 400 kişiye uygulanan araştırmada bilgiler araştırmacılar tarafindan hazırlanan anketle toplanmıştır. Araştırmada elde edilen bilgiler bilgisayarda istatistik programı ile analiz edilmiş ve tablolar halinde sunulmuştur. Rekreasyon alanları ile ilgili görüşler ki kare analizi yapılarak değerlendirilmiştir.

Anahtar Kelimeler: Rekreasyon, Rekreasyon Alanları, Ordu, Kent, Rekreatif Faaliyetler.

\section{City and Recreation (Sample of Ordu City)}

\begin{abstract}
This research focuses on how and where people living in Ordu city make use of their spare time, how often they use recreation areas and what their views on various recreation areas are. Analysis towards having more qualified spare time and more various recreation areas for those living in Ordu city constitutes the research object, as well. In this regard, views on recreation areas were considered within the context of sex, age, education, income, occupation, being local inhabitant of Ordu (or not), living in metropolitan (or not). The research was conducted at Altınordu district of Ordu between June - October, 2015. The research was applied to 400 people with random sampling and information was gathered through survey prepared by researchers. Information obtained in the research was analyzed with statistical programme in computer and presented as tables. Views on recreation areas were assessed by chi square analysis.
\end{abstract}

Keywords: Recreation, Recreation Areas, Ordu, City, Recreative Activities.

* Bu çalışma 6-10 Eylül 2017 tarihinde Bosna'da düzenlenen Uluslararası Peyzaj Mimarlığı Kongresi’nin özet metin kitapçı̆̆ında yayınlanmıştır. 


\section{Giriş}

Kent, insanlığın ilk evresinden günümüze kadar uzanan bir olgudur. Kentlerin ortaya çıkışı uygarlıkların doğuşu ile özdeşleştirilmektedir. Bir diğer ifadeyle, kent ve uygarlıklar birlikte gelişmişlerdir (Braudel 2014: 48; Çiftçi 2011: 75). Doğal kaynakların sunduğu olanaklardan yararlanmak amacıyla bir araya gelerek yerleşik hayata geçen ilk insanlar, kentlerin ortaya çıkmasının öncüleri olmuşlardır (Özer 2006: 271). İlerleyen dönemlerde gelişen ulaşım, sağlık, eğitim ve sosyal olanaklar ile ulaşılan yüksek yaşam standardı ve sosyalleşme ihtiyacı gibi bir çok neden insanların bir arada yaşamalarını zorunlu kılmış, zaman içerisinde artış gösteren nüfus ile kentlerin büyümelerini sağlayarak kentleşme sürecini başlatmıştır (Yeşil ve Yüksel 2016: 45). Kentleşme ile dar alanda artan nüfus ve beraberinde çeşitlenen ihtiyaçlar üretimin kentte yoğunlaşmasına neden olmuş bununla birlikte mekanın kullanım yoğunluğu da artmıştır (Serter 2013: 68). Yoğun yerleşimlere maruz kalan kentsel alanlar insanların yaşayabilecekleri mekânlar olmaktan çıkıp yaşamak zorunda kaldığı mekânlar haline dönüşmüştür (Şimşek ve Korkut 2009: 316).

Kentlerde yaşayan insanların genellikle birbirini tanımaması kişisel ilişkilerin zayıf ve yüzeysel kalmasına neden olmaktadır. Diğer taraftan iş ve meslek yaşantısının oldukça katı kurallara bağlı olması, kent insanının çabuk yıpranmasına sebep olmaktadır. Endüstri faaliyetlerinin yoğun olarak gerçekleştiği kentlerde hızlı nüfus artışı ve bazı çevre sorunlarının varlığı da insan hayatını güçleştiren diğer faktörlerdir. Bütün bunlar dikkate alındığında insanların günlük streslerden uzaklaşmak ve dinlenmek için yapacakları etkinliklerin önemi daha da artmaktadır (Akova 2012: 11).

Kentler, günümüzde sunduğu bu rekreatif faaliyetler veya rekreasyon alanları ile ön plana çıkmakta ya da bir cazibe merkezine dönüşmektedir. Sakinlerine sunduğu bu imkanların ötesinde, kentte özgü geliştirdiği bir takım rekreatif faaliyetler kentin marka olasına da önemli katkılar sağlamaktadır. Sonuçta rekreatif faaliyetler günümüz kentleri ve sakinleri için olmazsa olmaz faaliyetler arasındadır. 


\section{Kent ve Rekreasyon}

Kentlerin ilk ortaya çıkışı antik döneme kadar uzanmaktadır. Bu dönemde kentler bilimin, sanatın ve kozmopolit kültürün merkezi olsalar da, günümüz modern kentlere kıyasla özellikle nüfuslarının çok az olduğu görülmektedir. Günümüzdeki şekliyle büyük modern kentlerin ilk ortaya çıkışı sanayileşme süreci ile doğrudan ilişkilidir. İngiltere'de başlayan sanayileşme süreci, insanların yoğun bir şekilde kırsal alanlardan kasaba ve köylere taşınmasına ve milyonlarca insanın yaşadığı modern kentlerin ortaya çıkmasına neden olmuştur. Kentleşme, özellikle ekonomik kaygılar taşıyan insanların kent merkezlerine doğru olan hareketliliğiyle gelişmiş ülkelerinde içinde yer aldığı, bütün dünyayı etkileyen küresel bir sürece dönüşmüştür. Bir diğer ifadeyle, hem gelişmiş dünyada hem de gelişmekte olan dünyada insanların büyük bir kısmı kent merkezlerinde yaşamaktadır (Giddens ve Sutton 2016: 224-226).

Günümüzde üretim, ticaret ve finans merkezi haline gelen kentler, bir taraftan önemli fırsatlara sahipken, diğer taraftan suç, şiddet ve eşitsizliğin mekanı haline geldikleri görülmektedir. Ayrıca, her geçen gün artan nüfus daha çok çevre sorununun da ortaya çıkmasına neden olmaktadır (Giddens ve Sutton 2016: 226, 227, 241-243). Ancak bugün sürdürülebilir kent kavramının tartışıldığı ve kentlerin nasıl daha yaşanılabilir alanlar olacağı konusunda da adımlar atıldı̆̆ı görülmektedir. Sürdürülebilir kent, bir taraftan çevreyi korurken, diğer taraftan kentin sağladığı olanakları ve kültürel çeşitliliği korumayı hedeflemektedir. Bu noktada, sürdürülebilir kent hedeflerine ulaşmak için yerel yönetimlere çok büyük işler düşmekte ve günümüz küresel dünyasında başarılı örneklerini görmekteyiz (Giddens ve Sutton 2016: 243-250). Neticede sürdürülebilir kent, çevre konusunda duyarlı insanların yaşadığı, kent sakinlerine yaşamlarını daha kaliteli hale getirecek çeşitli olanaklar sunan ve insanların uyum içinde yaşadığı bir kente atıf yapmaktadır.

Dünya üzerindeki kentler çeşitli tasniflerle ortaya çıkmaktadır. Sassen'in küresel şehirler, Hall, Cohen ve Friedman'ın dünya şehirleri ve bunların dışında Türkiye'den İstanbul'unda içinde yer aldığı mega şehirler gibi sınıflamalar görülmektedir. Ayrıca, megalopolis olarak nitelendirilen, birbirleriyle bağlantılı birçok şehrin bir araya gelerek 
oluşturduğu devasa tek bir şehir örnekleri de mevcuttur (Ritzer 2011: 434-439; Davis 2007: 16-18; Konak 2011: 156). Bu tasnifler belirli kriterler esas alınarak yapılmakta ve buna göre dünya üzerindeki şehirler sıralanmaktadır. Ancak, bu şehirler hem uluslararası yatırımcılar hem de kent sakinleri açısından sundukları imkanlardan dolayı birer cazibe merkezi niteliğindedirler. Bu sınıflamalar içinde Türkiye'den kendine yer bulan tek şehir İstanbul'dur. Bir mega kent olarak İstanbul son yıllarda önemli altyapı, ulaşım ve sosyal yaşam alanları noktasında da önemli yatırımlar yapmakta ve kent hayatını daha yaşanabilir kılmak için çalışmalarını sürdürmektedir.

Kent; nüfusun büyük bölümünün ekonomik faaliyet alanı olarak ticaret, sanayi, yönetim ve hizmetle ilgili işlerle geçimini sağladığı, toplumsal ve kültürel bir örgütlenmenin olduğu yerleşim alanı (Yahyagil 1998: 105) olarak tanımlanabilir. Kaya’ya (2007: 6) göre; kent bir insanlar topluluğundan, kamu hizmetlerinden caddeler, binalar, elektrik lambaları, tramvaylar, telefonlar, kurumlar ve idari aygitlar toplamından fazla bir şeydir Bir kentin fiziksel yapısını, o kentte yaşayan insanların ekonomik, sosyal ve kültürel özellikleri ve birbirleriyle olan etkileşimleri oluşturur. Ancak günümüz kentlerinin kuruluş amaçları ne olursa olsun hemen hemen hepsinde toplumun yaşama, çalışma, eğlenme ve dinlenme etkinliklerine imkan sağlayan bölümler veya mekanlar bulunmaktadır. Bu mekanları işlevlerine göre yerleşim alanları, ticaret ve iş alanları, endüstri alanları, ulaşım alanları, sosyal tesisler, rekreasyonel alanlar ve doğal alanlar şeklinde sınıflandırmak mümkündür (Gül ve Küçük 2001:28).

Günümüzde teknolojik yenilikler insan yaşantısını kolaylaştırırken, bir takım sorunları da beraberinde getirmektedir. Örneğin; teknoloji insanların fizyolojik gereksinmelerinin karşılanmasını kolaylaştırmakta, ruhsal ve psikolojik gereksinmelerinde ise yalnız bırakmaktadır. Bu eksikliği giderme çabasında olan insanoğlu, iç dünyasını doyuma ulaştıracak çeşitli eylemlere yönelmektedir. Bu eylemler, bireyin çalışma dışı zamanlarda hoşlandığı bir işle uğraşması şeklinde olabilmekte ve insanoğlunu ruhsal ve bedensel açıdan yenilemektedir. İnsanoğlunun ruhsal ve bedensel açıdan yenilenmesini sağlayan boş zaman eylemleri, rekreasyon kavramı ile tanımlanmakta ve açıklanmaktadır (Tolunay vd., 2004: 59; Karaküçük 
2001: 55-56). McLean, Hurd ve Rogers (2008: 2) rekreasyonu; “şehir, kasaba ve ilçelerdeki; eğlence alanları, parklar, oyun alanları, su merkezleri ve spor alanlarında yapılan etkinlikler” şeklinde tanımlamışlardır.

Kent, insanların yoğun olarak yaşadığı, insanların sürekli aynı işi yapma neticesinde hayatlarının monotonlaştığı, ikincil ilişkilerin öne çıktığı, insanların kalabalıklar içinde yalnızlaştığı, belirli bir ücret karşılığında belirli bir süre çalıştığı ve çeşitli alanlarda uzmanlaşmanın yaşandığı bir mekan olarak karşımıza çıkmaktadır. İnsanlar yaşadığı bu tekdüze hayattan kurtulmak ve yeni insanlar tanımak için çeşitli rekreasyonel faaliyetlere ve mekanlara ihtiyaç duymaktadır. Bundan dolayı, günümüz modern kentleri, sakinlerinin yaşam kalitelerini arttırmak için rekreatif faaliyetler ve mekanlar konusunda önemli çalışmalar yürütmektedirler.

Teknolojik gelişmelerle insanların serbest zamanlarının artışı, eğitim ve gelir düzeylerinin yükselmesi ile yaşam sürelerinin uzaması gibi etkenler sonucu rekreasyonel etkinliklere olan talep artmıştır (Mansuroğlu 2002: 53). Akten ve Gül'e (2014: 130) göre; günümüzde sosyal, ekonomik, kültürel, teknolojik ve siyasal gelişmelere paralel olarak, özellikle kentleşme eğiliminin ortaya koyduğu olumlu ve olumsuz sonuçlar rekreasyonel/turizm talep ve çeşitliliği konusunda önemli değişim ve gelişmelere yol açmaktadır.

Rekreasyonel planlamanın tarihsel gelişimi incelendiğinde günün koşullarına göre temel kavram ve standartlar açısından sürekli bir değişim ya da atılım içerisinde bulunduğu gözlenebilir. Günümüzde geçerli olan rekreasyonel kavramlar ve standartlar, bundan 200 yıl öncesi için uygun olmayabilir. Ülkemizin de içerisinde yer aldığı bir çok gelişmekte olan ülkede rekreasyonel planlama politikasının yanılgısı, fiziksel planlamalarda rekreasyon kavramlarının öncelik sıralamasında sonlarda yer alması ve rekreasyonel planlama kararlarının günlük ya da kısa vadeli belirlemelere dayanmasından kaynaklanmaktadır (Altunkasa 2013: 1-79). 


\section{Uygulamalı Araştırma ve Sonuçları}

\subsection{Araştırma Yöntemi}

Araştırma konuyla ilgili kitap, makale, dergi vb. yazılı kaynakların incelenmesini ifade eden literatür taraması ve birinci kaynaklardan veri toplamada kullanılan ve en yaygın niceliksel araştırma yöntemlerinden birisi olan anket tekniği ile yapılmıştır.

\subsection{Araștırmanın Konusu ve Amacı}

Araştırmanın konusunu, Ordu kentinde yaşayan insanların katıldığı rekreatif faaliyetler, bu faaliyetlerin yapıldı̆̆ı yer ve bu faaliyetlere ayrılan zaman ile çeşitli rekreasyon alanları ile ilgili görüşleri oluşturmaktadır. Ordu halkının rekreatif eğilimleri ve rekreasyon alanlarına yönelik analizler de araştırmanın amacını teşkil etmektedir. Bu kapsamda, rekreasyon alanları ile ilgili çeşitli hususlar, cinsiyet, yaş, eğitim, gelir, meslek, Ordulu olma(ma), büyükş̧ehirde yaşama(ma) eksenlerinde değerlendirilmiştir.

\subsection{Araştırmanın Hipotezi}

Ordu kenti rekreasyon alanları açısından yeterli imkanlara sahip değildir.

\subsection{Evren ve Örnekleme}

Ordu Kenti 2013 yılında yapılan kanuni düzenleme ile Türkiye'nin 30. Büyükşehir'i olmuştur. Merkez ilçesi Altınordu olan kent, 19 ilçeden oluşmaktadır (T.C. Çevre ve Şehircilik Bakanlığı, 2015). ADNKS'nin 2016 yılı verilerine göre Ordu kentinin nüfusu 750.588, Altınordu ilçesinin nüfusu ise 205.396'dır (TÜİK, 2016).

Araştırmanın evrenini, Altınordu ilçesinde özellikle kentsel nüfusun yoğun olduğu mahallelerde yaşayan kişiler oluşturmaktadır. Araştırma, tesadüfi örnekleme tekniği ile 400 kişiye uygulanmıştır.

\subsection{Anket Formu ve Araştırmanın Uygulanması}

Araştırmanın uygulama sürecinde, araştırmaya katılmayı kabul eden kişilere ilk önce cinsiyet, yaş, eğitim düzeyi, gelir dururumu, meslek, memleket ve büyükşehirde 
yaşam durumlarının da yer aldığı toplamda 12 sorunun olduğu genel sorular sorulmuştur. Sonrasında serbest zamanlarını nasıl, nerede ve ne sıklıkla değerlendirdiği ve rekreasyon alanları ile ilgili soruların yer aldığı anket formu uygulanmıştır. Özellikle kentin sorunlarıyla ilgili sorular açık uçlu olarak sorulmuş ve bu sorulara verilen cevaplar araştırmacılar tarafından kategorize edilerek değerlendirilmiştir. Anket 2015 yılının Haziran ayında uygulanmaya başlanmış ve aynı yılın Ekim ayında tamamlanmıştır.

\subsection{Verilerin Analizi}

Araştırmaya katılan kişilerin serbest zamanlarını nasıl, nerede ve ne sıklıkla değerlendirdikleri ile Ordu kentinin sorunlarına yönelik frekans tabloları oluşturulmuş ve katılımcıların rekreasyon alanları ile ilgili her bir soruya vermiş oldukları yanıtların, cinsiyet, yaş, eğitim, gelir, meslek, Ordulu olma(ma) ve büyükşehirde yaşama(ma) değişkenleri ile arasındaki ilişki ki-kare testi ile ölçülmüş̧ür.

\subsection{Araştırmanın Geçerliliği ve Güvenilirliği}

Araştırmada rekreasyon alanları için katılımcıların vermiş olduğu yanıtların güvenirliği $\alpha$ katsayısı kullanılarak hesaplanmış ve 0,761 olarak bulunmuştur.

\section{Bulgular ve Yorumlar}

\subsection{Araştırma Grubunun Rekreatif Eğilimleri}

$\mathrm{Bu}$ bölümde araştırma grubunun katıldığı rekreatif faaliyetler, rekreatif faaliyetlere ayrılan zaman, serbest zamanlarını nerede değerlendirdikleri ve Ordu kentinin sorunları incelenmiştir. $\mathrm{Bu}$ özelliklerin her birinin frekans tabloları oluşturulmuştur.

\subsubsection{Rekreatif Faaliyetler}

Araştırmaya katılanların serbest zamanlarında ne tür rekreatif faaliyetlere katıldıkları Tablo 1'de görülmektedir. Buna göre katılımcıların yarısının ara sıra televizyon izlediği ve her zaman ya da sıklıkla kitap, gazete okuduğu görülmektedir. 
Katılımcıların \% 60'dan daha fazlasının sinemaya ve çeşitli kurslara, dörtte üçünün ise tiyatro ve konsere nadiren gittiği ya da hiçbir zaman gitmediği ortaya çıkmıştır. Bu oranların yüksek olması, kentin sakinlerine bu alanlarda yeterince imkan sunmamasıyla ilişkili olabilir. Bir diğer sonuca göre, katılımcıların \% 47'sinin tatile, \% 57'sinin kafeye ve \% 84'ünün kahveye nadiren gittiği ya da hiçbir zaman gitmediği anlaşılmaktadır. Bir diğer açıdan katılımcıların \% 55'inin her zaman ya da sıklıkla müzik dinlediği, \% 40'dan daha fazlasının ara sıra spor yaptı̆ğ, arkadaşlarıyla bir araya geldikleri ve alışveriş yaptıkları görülmektedir. Özellikle her zaman ve sıklıkla spor yapanların oranının \% 24 olması spor tesislerinin yetersizliği ile ilişkili olabilir. Katılımcıların yaklaşık yarısının ara sıra ailece pikniğe gittiği ve \% 40'dan daha fazlasının akraba ziyaretinde bulunduğu görülmektedir. Son olarak katılımcıların \% 67'sinin internette çeşitli amaçlarla gezindiği görülmektedir.

Tablo 1. Serbest Zamanlarda Yapılan Rekreatif Faaliyetler

\begin{tabular}{|l|c|c|c|c|c|c|c|c|c|c|}
\hline & \multicolumn{2}{|c|}{$\begin{array}{c}\text { Her } \\
\text { zaman }\end{array}$} & \multicolumn{2}{c|}{ Sıklıkla } & \multicolumn{2}{c|}{ Ara sıra } & \multicolumn{2}{c|}{ Nadiren } & \multicolumn{2}{c|}{$\begin{array}{c}\text { Hiçbir } \\
\text { zaman }\end{array}$} \\
\cline { 2 - 13 } & $\mathbf{N}$ & $\mathbf{\%}$ & $\mathbf{N}$ & $\mathbf{\%}$ & $\mathbf{N}$ & $\mathbf{\%}$ & $\mathbf{N}$ & $\mathbf{\%}$ & $\mathbf{N}$ & $\mathbf{\%}$ \\
\hline Televizyon izlemek & 29 & 7.3 & 81 & 20.2 & 206 & 51.5 & 76 & 19.0 & 8 & 2.0 \\
\hline Kitap,gazete okumak & 58 & 14.5 & 128 & 32.0 & 143 & 35.8 & 64 & 16.0 & 7 & 1.8 \\
\hline Sinemaya gitmek & 4 & 1.0 & 19 & 4.8 & 130 & 32.5 & 196 & 49.0 & 51 & 12.8 \\
\hline Tiyatroya gitmek & 6 & 1.5 & 14 & 3.5 & 82 & 20.5 & 190 & 47.5 & 108 & 27.0 \\
\hline Konsere gitmek & 4 & 1.0 & 10 & 2.5 & 79 & 19.8 & 196 & 49.0 & 111 & 27.8 \\
\hline Tatile gitmek & 11 & 2.8 & 46 & 11.5 & 158 & 39.5 & 134 & 33.5 & 51 & 12.8 \\
\hline Müzik dinlemek & 85 & 21.2 & 135 & 33.8 & 116 & 29.0 & 51 & 12.8 & 13 & 3.2 \\
\hline Spor yapmak & 26 & 6.5 & 69 & 17.2 & 165 & 41.2 & 104 & 26.0 & 36 & 9.0 \\
\hline Arkadaş toplantıları & 40 & 10.0 & 112 & 28.0 & 168 & 42.0 & 71 & 17.8 & 9 & 2.2 \\
\hline Ailece pikniğe gitmek & 18 & 4.5 & 69 & 17.2 & 191 & 47.8 & 105 & 26.2 & 17 & 4.2 \\
\hline Alısveriş yapmak & 36 & 9.0 & 128 & 32.0 & 163 & 40.8 & 64 & 16.0 & 9 & 2.2 \\
\hline Akraba ziyaretinde bulunmak & 35 & 8.7 & 102 & 25.5 & 174 & 43.5 & 77 & 19.2 & 12 & 3.0 \\
\hline Çeşitli kurslara gitmek & 7 & 1.7 & 24 & 6.0 & 99 & 24.8 & 157 & 39.2 & 113 & 28.2 \\
\hline Kahveye gitmek & 13 & 3.3 & 17 & 4.2 & 32 & 8.0 & 73 & 18.2 & 265 & 66.2 \\
\hline Kafeye gitmek & 17 & 1.5 & 30 & 7.5 & 127 & 31.8 & 131 & 32.8 & 95 & 23.8 \\
\hline İnternet (haber, bilgi, sosyal medya vb.) & 117 & 29.3 & 152 & 38.0 & 67 & 16.8 & 32 & 8.0 & 32 & 8.0 \\
\hline
\end{tabular}




\subsubsection{Rekreatif Faaliyetlere Ayrilan Zaman}

Araştırma grubunun rekreatif faaliyetlere katılma sıklı̆̆ı Tablo 2'de görülmektedir. Araştırmaya katılan kişilerin büyük bir kısmının rekreasyon alanlarını düzenli kullanmadıkları görülmektedir. Buna göre, firsat buldukça ve yaz aylarında kullananların oranı \% 61 olduğu görülmektedir.

Tablo 2- Rekreasyon Alanlarını Kullanma Sıklığı

\begin{tabular}{|l|c|c|}
\hline & N & \% \\
\hline Firsat buldukça & 214 & 53.5 \\
\hline Yaz aylarında & 31 & 7.8 \\
\hline Hafta sonları & 97 & 24.2 \\
\hline 3-4 günde bir & 27 & 6.8 \\
\hline Gün aşırı & 17 & 4.2 \\
\hline Her gün & 14 & 3.5 \\
\hline Toplam & 400 & 100.0 \\
\hline
\end{tabular}

\subsubsection{Serbest Zaman Değerlendirme Yeri}

Araştırma grubunun serbest zamanlarını değerlendirme yerleri açık uçlu bir soruyla araştırılmış; sonuçlar Tablo 3 'te verilmiştir. Araştırma bulgularına göre katılımcıların serbest zamanlarını daha çok evde geçirdikleri görülmektedir. Evin dışında ise sahil ve alışveriş merkezleri insanların yoğunlukla zaman harcadıkları yerler olduğu anlaşılmaktadır. Özellikle spor tesisleri ve kültür-sanat merkezlerinde harcanan zamanın az olması, bu rekreatif alanların kentte yeterince olmamasiyla ilişkilendirilebilir.

Tablo 3- Serbest Zamanları Değerlendirme Yeri

\begin{tabular}{|l|c|c|}
\hline & N & \% \\
\hline Evde & 354 & 88.5 \\
\hline Sahilde & 228 & 57.0 \\
\hline Alışveriş Merkezlerinde & 161 & 40.2 \\
\hline Parklarda & 108 & 27.0 \\
\hline Kafede/Kahvede & 98 & 24.5 \\
\hline Mesire Alanlarında & 88 & 22.0 \\
\hline Spor Tesislerinde & 63 & 15.8 \\
\hline
\end{tabular}




\begin{tabular}{|l|c|c|} 
Kültür-Sanat Merkezlerinde & 63 & 15.8 \\
\hline Okulda & 60 & 15.0 \\
\hline Diğer & 56 & 14.0 \\
\hline
\end{tabular}

\subsubsection{Ordu Kentinin Sorunları}

Katılımcılara “sizce Ordu'nun en önemli ilk üç sorunu nedir?” diye bir soru yöneltilmiş ve verilen cevaplar büyüklük sırasına göre Tablo 4’te sıralanmıştır. Toplamda 53 sorun tespit edilmiştir. Aşağıdaki tabloda bu sorunlardan ilk 23'ü sıralanmıştır. Buna göre, rekreasyon alanlarının yetersizliği \% 13,8 ile 6 . sırada, günümüzde rekreatif faaliyetlerin önemli mekanları haline gelen alışveriş merkezleri eksikliği \% 9,8 ile 9. sırada ve rekreatif faaliyetlerin yetersizliği ise \% 8,7 ile 10. sırada yer almaktadır. Bir diğer açıdan sonuçları değerlendirdiğimizde ise, bu üç sorunun \% 32,3 ile 3. sirada yer alması Ordu kentinin hem rekreasyon alanları hem de rekreatif faaliyetler açısından önemli eksiklikleri olduğu görülmektedir.

Tablo 4. Ordu Kentinin Sorunları

\begin{tabular}{|l|c|c|}
\hline \multicolumn{3}{|c|}{ Sizce Ordu'nun en önemli ilk üç sorunu nedir? } \\
\hline & $\mathbf{N}$ & $\%$ \\
\hline Trafik & 201 & 50.3 \\
\hline Altyapı/Üstyap1 & 173 & 43.2 \\
\hline Ulaşım & 97 & 24.2 \\
\hline Çarpık Kentleşme & 82 & 20.5 \\
\hline İşsizlik & 75 & 18.7 \\
\hline Rekreasyon Alanlarının Yetersizliği & 55 & 13.8 \\
\hline Çevre Kirliliği & 50 & 12.5 \\
\hline Otopark & 49 & 12.2 \\
\hline Alışveriş Merkezleri & 39 & 9.8 \\
\hline Sosyo-Kültürel Faaliyetlerin Yetersizliği & 35 & 8.7 \\
\hline Çöp & 31 & 7.8 \\
\hline Pahalılık & 27 & 6.7 \\
\hline İçme Suyu & 27 & 6.7 \\
\hline Çevre Düzenlemesi & 26 & 6.5 \\
\hline Sanayinin Olmaması & 23 & 5.8 \\
\hline Ĕğitim Düzeyi & 14 & 3.4 \\
\hline İnsan Davranışları & 14 & 3.4 \\
\hline İstihdam & 13 & 3.3 \\
\hline Turizm & 13 & 3.3 \\
\hline Esnaf Davranışları & 12 & 3.0 \\
\hline
\end{tabular}




\begin{tabular}{|l|l|l|} 
Kent Kültürü & 9 & 2.3 \\
\hline Sağlık Hizmetlerinin Yetersizliği & 8 & 2.0 \\
\hline Yerel Yönetimlerin Sorunlara Çözüm Üretememesi & 8 & 2.0 \\
\hline
\end{tabular}

\subsection{Araştırma Grubunun Demografik Özellikleri ve Rekreasyon Alanları} İlişkisi

$\mathrm{Bu}$ bölümde ise araştırmaya katılan kişilerin, cinsiyet, yaş, eğitim, gelir, meslek, Ordulu olma(ma), büyükşehirde yaşama(ma) ekseninde, rekreasyon alanları ile ilişkisi incelenmiştir. $\mathrm{Bu}$ ilişkinin düzeyi çapraz tablolar ve ki-kare analizi yapılarak ortaya konulmaya çalışılmıştır. Ki kare analizinin yapılamadığı yerlerde değişkenler arasında mantıksal olarak tutarlı birleştirmeler yapılmıştır. Ayrıca, ki-kare analizinin yapılamadığı veya anlamlı ilişki bulunamadığı yerlerde sonuçlar oransal eğilimler üzerinden yorumlanmıştır.

Katılımcılara yöneltilen soruların her biri ayrı ayrı cinsiyet, yaş, eğitim, gelir, meslek, Ordulu olma(ma), daha önce büyükşehirde yaşama(ma) ekseninde incelenmiş "kesinlikle katılmıyorum" ve "katılmıyorum" kategorilerinin birleştirilmiş yüzdeleri ile p değerleri tabloda belirtilmiştir.

\subsubsection{Cinsiyet ve Rekreasyon}

Cinsiyet ve rekreasyon alanları arasındaki ilişki Tablo 5'te görülmektedir. Buna göre, cinsiyet ile kentte yeterince tiyatro ve sinema vardır ile kentin gençlik merkezlerine ihtiyacı vardır arasında anlamlı ilişki bulunmuştur. Buna göre erkeklerin yarısı, kadınların \% 64'ü kentte yeterli tiyatro ve sinema olmadığını düşünmektedir. Bu noktada kadınların tiyatro ve sinema gibi rekreasyon alanlarına daha çok önem verdileri görülmektedir. Bir diğer sonuca göre, kadınların \% 94'ü erkeklerin ise \% 96'sı kentin gençlik merkezlerine ihtiyacı olduğunu belirtmişlerdir. Diğer hususlarda ki kare analizi yapılamamış veya anlamlı ilişki bulunamamıştır. Ancak oransal eğilimler üzerinden sonuçları değerlendirdiğimizde kadınların \% 97'si, erkeklerin \% 94'ü sahildeki yürüyüş ve bisiklet yollarının ayrılması ve kadınların \% 93'ü, erkeklerin \% 96'sı yayalara özel yeni caddeler oluşturulması gerektiğini belirtmişlerdir. Kültür ve sanat merkezlerinin 
yeterli olmadığını düşünen kadınların oranı \% 60 iken, erkeklerin oranı \% 52'dir. Aynı şekilde tiyatro ve sinema hususunda olduğu gibi, kadınların kültür ve sanat konusuna erkeklere kıyasla biraz daha önem verdikleri görülmektedir. Bir diğer önemli bulguya göre, kadınların \% 89'u, erkeklerin \% 87'si kentin büyük bir kütüphaneye ihtiyacı olduğunu düşünmektedirler. Diğer hususlarda kadın ve erkekler arasında önemli farklılıklar bulunmamaktadır. Bun göre, katılımcıların hemen hemen \% 60'dan fazlası, açık ve kapalı spor alanlarının, kent merkezindeki parkların ve yeşil alanların, mesire alanlarının, sahildeki mekan ve aktivite alanlarının yeterli olmadığını belirtmişlerdir. Ayrıca katılımcıların neredeyse \% 80'inin rekreatif alanların engellilerin kullanımına uygun olmadığını ve yaklaşık \% 70'inin ise rekreasyon alanlarının kentte dengeli dağılmadığını belirtmişlerdir. Sonuç olarak her iki cinsiyet açısından kendi içinde birtakım farklılıklar olsa da, rekreasyon alanları noktasında kentin önemli eksiklikleri olduğu görülmektedir.

Tablo 5- Cinsiyet ve Rekreasyon Alanları İlişkisi

\begin{tabular}{|l|c|c|c|}
\hline \multirow{2}{*}{} & \multicolumn{2}{|c|}{ Cinsiyet (\%) } \\
\cline { 2 - 4 } & Kadın & Erkek & p \\
\hline Açık spor alanları yeterlidir & 56.5 & 59.9 & 0.717 \\
\hline Kapalı spor alanları yeterlidir & 64.8 & 62.2 & 0.834 \\
\hline Sahildeki yürüyüş ve bisiklet yolları ayrılmalıdır & 3.4 & 6.3 & - \\
\hline Kent merkezinde yeterince park vardır & 69.1 & 69.5 & 0.811 \\
\hline Kent merkezindeki yeşıl alan miktarı yeterlidir & 65.5 & 67.6 & 0.666 \\
\hline Kültür ve sanat merkezleri yeterlidir & 59.7 & 51.8 & 0.190 \\
\hline Kentte yeterince tiyatro ve sinema vardır & 64.4 & 49.5 & $\mathbf{0 . 0 1 0}$ \\
\hline Eğlence mekanları (disko, türkü bar vb.) yeterlidir & 36.7 & 38.7 & 0.067 \\
\hline Mesire alanları yeterlidir & 55.4 & 55.9 & 0.988 \\
\hline Rekreatif alanlar engellilerin kullanımına uygundur & 79.2 & 74.7 & 0.560 \\
\hline Sahilde zaman geçirmek için mekanlar-aktivite alanları & 59.9 & 61.3 & 0.795 \\
\hline yeterlidir & 10.7 & 12.6 & 0.200 \\
\hline Kentin büyük bir kütüphaneye ihtiyacı vardır & 6.2 & 3.6 & $\mathbf{0 . 0 1 6}$ \\
\hline Kentin gençlik merkezlerine ihtiyacı vardır & 6.8 & 3.6 & 0.099 \\
\hline Yayalara özel yeni caddeler oluşturulmalıdır & 66.7 & 65.8 & 0.763 \\
\hline Rekreasyon alanları kentte dengeli dağılmıştır & & & \\
\hline
\end{tabular}




\subsubsection{Yaş ve Rekreasyon}

Yaş ve rekreasyon alanları arasındaki ilişki Tablo 6'da görülmektedir. Yaş ile kent merkezindeki yeşil alan miktarı yeterlidir, kültür ve sanat merkezleri yeterlidir ve eğlence mekanları yeterlidir arasında anlamlı ilişki bulunmuştur. Buna göre, 45-54 yaş aralığındaki kişilerin yaklaşık \% 80’i kent merkezindeki yeşil alan miktarını yeterli görmemektedirler. Ayrıca, 25 yaşından 54 yaşına doğru yeşil alanları yeterli görmeyenlerin oranının \% 53’ten \% 79'a çıkmasını, bu kişilerin iş yaşamının yoğunluğundan kaçmak ve aileleri ile birlikte zaman geçirmek istemesinden dolayı bu alanlara daha fazla ihtiyaç duymasıyla açıklanabilir. Kültür ve sanat merkezlerinin daha çok 15-24 ile 35-54 yaş aralığındaki kişiler yeterli olmadığını düşünmektedirler. Eğlence mekanlarına daha çok ihtiyaç duyanların gençler olduğu (\% 54), tam tersi en az ihtiyaç duyanların ise yaşlıların olduğu $(\%$ 12) görülmektedir. $\mathrm{Bu}$ durum yaşlıların gençlere kıyasla daha sakin bir hayat istemesiyle açıklanabilir. Diğer hususlarda ki kare analizi yapılamamış veya anlamlı ilişki bulunamamıştır. Ancak oransal eğilimler üzerinden sonuçları değerlendirdiğimizde açık ve kapalı spor alanlarının yeterli olmadığını en çok 45-54 yaş aralığında olanlar, en az ise 55 ve üstü yaşta olanlar belirtmişlerdir. Kent merkezindeki parkların ve mesire alanlarının yeterli olmadığını düşünenlerin oranı 15 yaşından 54 yaşına doğru artmaktadır. Bir diğer ifadeyle yaş ilerledikçe bu alanlara olan ihtiyaç değişen şartlara (iş hayatı, evlilik, çocuk vb.) bağlı olarak artmasıyla ilişkilendirilebilir. Ayrıca, 55 ve üstü yaşta olanların \% 69’u mesire alanlarının yeterli olduğu düşünmektedir. Katılımcıların yaş fark etmeksizin \% 90'dan daha fazlasının sahildeki bisiklet ve yürüyüş yollarının ayrılması gerektiğini, kentin büyük bir kütüphaneye, gençlik merkezlerine, yayalara özel yeni caddelere ihtiyac1 olduğunu belirtmişlerdir. Kentte tiyatro ve sinemaya ihtiyaç duyanların oranının yaş arttıkça azaldığı görülmektedir. Bir diğer ifadeyle bu oran 15-24 yaş aralığında \% 77 iken, 55 ve üstü yaş grubunda \% 41'e düşmektedir. Katılımcıların dörtte üçü, rekreasyon alanlarının engellilerin kullanımına uygun olmadığını düşünmektedir. 
Tablo 6- Yaş ve Rekreasyon Alanları İlişkisi

\begin{tabular}{|l|c|c|c|c|c|c|}
\hline & \multicolumn{5}{|c|}{ Yaş (\%) } \\
\cline { 2 - 7 } & $\mathbf{1 5 - 2 4}$ & $\mathbf{2 5 - 3 4}$ & $\mathbf{3 5 - 4 4}$ & $\mathbf{4 5 - 5 4}$ & $\begin{array}{c}\mathbf{5 5} \text { ve } \\
\text { üstü }\end{array}$ & p \\
\hline Açık spor alanları yeterlidir & 51.3 & 55.1 & 61.8 & 63.8 & 47.1 & 0.441 \\
\hline Kapalı spor alanları yeterlidir & 66.7 & 59.1 & 63.7 & 71.2 & 47.1 & 0.359 \\
\hline Sahildeki yürüyüş ve bisiklet yolları ayrılmalıdır & 5.1 & 2.3 & 8.1 & 3.8 & 5.9 & - \\
\hline Kent merkezinde yeterince park vardır & 48.7 & 67.2 & 73.1 & 76.2 & 70.6 & 0.079 \\
\hline Kent merkezindeki yeşil alan miktarı yeterlidir & 61.5 & 53.1 & 75.0 & 78.5 & 58.8 & $\mathbf{0 . 0 0 4}$ \\
\hline Kültür ve sanat merkezleri yeterlidir & 59.0 & 44.5 & 60.9 & 62.0 & 52.9 & $\mathbf{0 . 0 3 5}$ \\
\hline Kentte yeterince tiyatro ve sinema vardır & 76.3 & 55.5 & 58.1 & 47.5 & 41.2 & 0.053 \\
\hline $\begin{array}{l}\text { Eğlence mekanları (disko, türkü bar vb.) } \\
\text { yeterlidir }\end{array}$ & 53.8 & 36.7 & 42.2 & 30.0 & 11.8 & $\mathbf{0 . 0 0 0}$ \\
\hline Mesire alanları yeterlidir & 44.7 & 55.5 & 58.1 & 62.5 & 29.4 & 0.072 \\
\hline $\begin{array}{l}\text { Rekreatif alanlar engellilerin kullanımına } \\
\text { uygundur }\end{array}$ & 76.9 & 74.2 & 81.5 & 72.5 & 76.5 & - \\
\hline $\begin{array}{l}\text { Sahilde zaman geçirmek için mekanlar-aktivite } \\
\text { alanları yeterlidir }\end{array}$ & 66.7 & 57.0 & 63.7 & 57.5 & 64.7 & 0.111 \\
\hline Kentin büyük bir kütüphaneye ihtiyacı vardır & 5.1 & 6.2 & 17.6 & 15.0 & 5.9 & - \\
\hline Kentin gençlik merkezlerine ihtiyacı vardır & 5.1 & 2.3 & 7.4 & 5.0 & - & - \\
\hline Yayalara özel yeni caddeler oluşturulmalıdır & 5.1 & 3.1 & 7.4 & 5.1 & - & - \\
\hline Rekreasyon alanları kentte dengeli dağılmışır & 53.8 & 60.9 & 72.8 & 67.1 & 76.5 & 0.109 \\
\hline
\end{tabular}

\subsubsection{Eğitim ve Rekreasyon}

Eğitim ve rekreasyon alanları arasındaki ilişki Tablo 7'de görülmektedir. Eğitim ve rekreasyon alanları arasında ki kare analizi yapılamamıştır. Araştırma bulguları oransal eğilimler üzerinden incelendiğinde, kentteki yeşil alanların, kültür ve sanat merkezlerinin, sahildeki mekan ve aktivite alanlarının eğitim düzeyi arttıkça yeterli olmadığı görülmektedir. Bir diğer ifadeyle eğitim düzeyi yüksek olanlar bu tür mekanların daha fazla olması gerektiğini belirtmişlerdir. Rekreasyon alanlarının engellilerin kullanımına uygun olmadığını düşünenler, ilkokul mezunlarında \% 42 iken, lisansüstü dereceye sahip olanlarda \% 80’e çıkmaktadır. Eğitim düzeyi fark etmeksizin katılımcıların \% 80'inden daha fazlası sahildeki yürüyüş ve bisiklet yollarının ayrılması gerektiğini, kentin büyük bir kütüphaneye ve gençlik merkezlerine ihtiyacı olduğunu ve yayalara özel yeni caddelerin oluşturulması gerektiğini belirtmişlerdir. Açık spor alanlarının yeterli olmadığını \% 77 ile ortaokul mezunu olanlar belirtirken, kapalı spor 
alanlarının yeterli olmadığını ise \% 83 ile ilkokul mezunu olanlar belirtmişlerdir. Kentin tiyatro ve sinema ile mesire alanlarına ihtiyacı olduğunu düşünenlerin oranı eğitim düzeyi yükseldikçe artmaktadır. Ayrıca kentteki rekreasyon alanlarının dengeli dağılmadığını ifade edenlerin oranı ilkokul mezunlarında \% 33 iken, lisansüstü dereceye sahip olanlarda \% 74'tür.

Tablo 7- Eğitim ve Rekreasyon Alanları İliş̧kisi

\begin{tabular}{|l|c|c|c|c|c|c|}
\hline & \multicolumn{5}{|c|}{ Ĕgitim (\%) } \\
\cline { 2 - 7 } & İlkokul & Ortaokul & Lise & Üniversite & Lisansüstü & p \\
\hline Açık spor alanları yeterlidir & 66.7 & 76.9 & 47.6 & 58.2 & 64.6 & - \\
\hline Kapalı spor alanları yeterlidir & 83.3 & 61.5 & 58.3 & 64.2 & 63.5 & - \\
\hline $\begin{array}{l}\text { Sahildeki yürüyüş ve bisiklet yolları } \\
\text { ayrılmalıdır }\end{array}$ & 16.7 & - & 6.0 & 4.1 & 5.2 & - \\
\hline Kent merkezinde yeterince park vardır & 75.0 & 76.9 & 59.8 & 68.7 & 77.1 & - \\
\hline $\begin{array}{l}\text { Kent merkezindeki yeşil alan miktarı } \\
\text { yeterlidir }\end{array}$ & 50.0 & 61.5 & 57.1 & 66.0 & 79.2 & - \\
\hline Kültür ve sanat merkezleri yeterlidir & 33.3 & 38.5 & 45.8 & 57.8 & 63.5 & - \\
\hline $\begin{array}{l}\text { Kentte yeterince tiyatro ve sinema } \\
\text { vardır }\end{array}$ & 33.3 & 61.5 & 53.6 & 58.8 & 55.2 & - \\
\hline $\begin{array}{l}\text { Eğlence mekanları (disko, türkü bar vb.) } \\
\text { yeterlidir }\end{array}$ & 41.7 & 30.8 & 40.5 & 40.2 & 31.2 & - \\
\hline Mesire alanları yeterlidir & 33.3 & 53.8 & 57.1 & 58.8 & 51.0 & - \\
\hline $\begin{array}{l}\text { Rekreatif alanlar engellilerin } \\
\text { kullanımına uygundur }\end{array}$ & 41.7 & 84.6 & 73.5 & 77.9 & 80.2 & - \\
\hline $\begin{array}{l}\text { Sahilde zaman geçirmek için mekanlar- } \\
\text { aktivite alanları yeterlidir }\end{array}$ & 41.7 & 46.2 & 53.6 & 61.3 & 69.8 & - \\
\hline $\begin{array}{l}\text { Kentin büyük bir kütüphaneye ihtiyacı } \\
\text { vardır }\end{array}$ & 16.7 & 7.7 & 13.1 & 13.8 & 6.2 & - \\
\hline $\begin{array}{l}\text { Kentin gençlik merkezlerine ihtiyacı } \\
\text { vardır }\end{array}$ & 16.7 & 7.7 & 4.8 & 4.6 & 3.1 & - \\
\hline $\begin{array}{l}\text { Yayalara özel yeni caddeler } \\
\text { oluşturulmalıdır }\end{array}$ & 25.0 & - & 3.6 & 5.6 & 3.1 & - \\
\hline $\begin{array}{l}\text { Rekreasyon alanları kentte dengeli } \\
\text { dağılmıştır }\end{array}$ & 33.3 & 83.3 & 63.1 & 64.6 & 74.0 & - \\
\hline
\end{tabular}

\subsubsection{Gelir ve Rekreasyon}

Gelir ve rekreasyon alanları arasındaki ilişki Tablo 8'de görülmektedir. Gelir ile eğlence mekanları yeterlidir, rekreasyon alanları engellilerin kullanımına uygundur ve rekreasyon alanları kentte dengeli dağılmıştır arasında anlamlı ilişki bulunmuştur. Buna göre gelir düzeyi 1000-2000 $€$ arasında olanların yaklaşık yarısı eğlence mekanlarının 
yeterli olmadığını belirtirken, gelir düzeyi 3001-5000 † arasında olanların ise \% 29'u yeterli olmadığını belirtmişlerdir. Rekreasyon alanlarının engellilerin kullanıma uygun olmadığını düşünenlerin oranı gelir düzeyi 1000 t’den az olanlarda \% 52 iken, gelir düzeyi 5001 †' den daha fazla olanlarda ise \% 83'tür. Bu durum gelir düzeyi yükseldikçe engelliler ile ilgili bilinç düzeyinin arttı̆̆ını göstermektedir. Aynı durum, rekreasyon alanları kentte dengeli dağılmıştır sorusunda da gözlenmektedir. Diğer hususlarda ki kare analizi yapılamamış veya anlamlı ilişki bulunamamıştır. Ancak oransal eğilimler üzerinden sonuçları değerlendirdiğimizde katılımcıların \% 85'inden daha fazlası gelir düzeyi fark etmeksizin, sahildeki yürüyüş ve bisiklet yollarının ayrılması gerektiğini, kentin büyük bir kütüphaneye ve gençlik merkezlerine ihtiyacı olduğunu ve yayalara özel yeni caddeler oluşturulması gerektiğini belirtmişlerdir. Kent merkezindeki yeşil alan miktarının yeterli olmadığını düşünenlerin oranı gelir düzeyi yükseldikçe artmaktadır. Açık ve kapalı spor alanlarının yeterli olmadığını daha çok gelir düzeyi 3001-5000 $t$ arasında olanlar belirtmişlerdir.

Tablo 8- Gelir ve Rekreasyon Alanları İlişkisi

\begin{tabular}{|l|c|c|c|c|c|c|}
\hline & \multicolumn{5}{|c|}{ Gelir (\%) } \\
\cline { 2 - 6 } & $\mathbf{1 0 0 0 <}$ & $\mathbf{1 0 0 0 - 2 0 0 0}$ & $\mathbf{2 0 0 1 - 3 0 0 0}$ & $\mathbf{3 0 0 1 - 5 0 0 0}$ & $\mathbf{5 0 0 1 >}$ & $\mathbf{p}$ \\
\hline Açık spor alanları yeterlidir & 52.4 & 50.8 & 53.7 & 66.1 & 59.4 & 0.526 \\
\hline Kapalı spor alanları yeterlidir & 61.9 & 54.0 & 62.1 & 66.7 & 66.3 & 0.249 \\
\hline $\begin{array}{l}\text { Sahildeki yürüyüş ve bisiklet } \\
\text { yolları ayrılmalıdır }\end{array}$ & 14.3 & 12.7 & 2.1 & 4.3 & 2.0 & - \\
\hline $\begin{array}{l}\text { Kent merkezinde yeterince park } \\
\text { vardır }\end{array}$ & 71.4 & 62.9 & 63.5 & 71.8 & 75.2 & 0.148 \\
\hline $\begin{array}{l}\text { Kent merkezindeki yeşil alan } \\
\text { miktarı yeterlidir }\end{array}$ & 47.6 & 61.9 & 61.5 & 70.9 & 74.3 & 0.051 \\
\hline $\begin{array}{l}\text { Kültür ve sanat merkezleri } \\
\text { yeterlidir }\end{array}$ & 33.3 & 60.3 & 51.0 & 55.3 & 61.4 & 0.171 \\
\hline $\begin{array}{l}\text { Kentte yeterince tiyatro ve sinema } \\
\text { vardır }\end{array}$ & 42.9 & 63.5 & 58.9 & 54.2 & 53.5 & 0.243 \\
\hline $\begin{array}{l}\text { Eğlence mekanları (disko, türkü } \\
\text { bar vb.) yeterlidir }\end{array}$ & 42.9 & 49.2 & 37.5 & 29.1 & 39.6 & $\mathbf{0 . 0 0 6}$ \\
\hline Mesire alanları yeterlidir & 52.4 & 49.2 & 53.7 & 58.5 & 58.4 & 0.883 \\
\hline $\begin{array}{l}\text { Rekreatif alanlar engellilerin } \\
\text { kullanımına uygundur }\end{array}$ & 52.4 & 66.7 & 80.0 & 78.0 & 83.2 & $\mathbf{0 . 0 4 0}$ \\
\hline $\begin{array}{l}\text { Sahilde zaman geçirmek için } \\
\text { mekanlar-aktivite alanları yeterlidir }\end{array}$ & 71.4 & 52.4 & 58.3 & 65.0 & 60.4 & 0.373 \\
\hline $\begin{array}{l}\text { Kentin büyük bir kütüphaneye } \\
\text { ihtiyacı vardır }\end{array}$ & 4.8 & 7.9 & 10.4 & 16.1 & 11.9 & 0.778 \\
\hline
\end{tabular}




\begin{tabular}{|l|c|c|c|c|c|c|}
$\begin{array}{l}\text { Kentin gençlik merkezlerine } \\
\text { ihtiyacı vardır }\end{array}$ & 4.8 & 6.3 & 5.2 & 7.6 & - & - \\
\hline $\begin{array}{l}\text { Yayalara özel yeni caddeler } \\
\text { oluşturulmalıdır }\end{array}$ & 9.5 & 7.9 & 3.1 & 6.8 & 2.0 & - \\
\hline $\begin{array}{l}\text { Rekreasyon alanları kentte dengeli } \\
\text { dağılmıştır }\end{array}$ & 57.1 & 54.0 & 65.6 & 70.9 & 70.3 & $\mathbf{0 . 0 2 8}$ \\
\hline
\end{tabular}

\subsubsection{Meslek ve Rekreasyon}

Meslek ve rekreasyon alanları arasındaki ilişki Tablo 9'da görülmektedir. Meslek ve rekreasyon alanları arasında ki kare analizi yapılamamıştır. Araştırma bulguları oransal eğilimler üzerinden incelendiğinde, açık ve kapalı spor alanlarının yeterli olmadığını düşünenlerin daha çok emekliler olduğu görülmektedir. Bu durum emeklilerin emeklilik sonrası serbest zamanlarının artması ve bu zamanlarını değerlendirmek için çeşitli mekan ve aktiviteler aramasıyla açıklanabilir. Araştırmaya katılanların \% 80'den daha fazlası mesleği fark etmeksizin sahildeki yürüyüş ve bisiklet yollarının ayrılması gerektiğini, kentin büyük bir kütüphaneye ve gençlik merkezlerine ihtiyacı olduğunu ve yaylara özel yeni caddeler oluşturulması gerektiğini belirtmişlerdir. Emeklilerin \% 82'si ve akademisyen, doktor, avukat vb. mesleğe sahip olanların \% 81'i, rekreasyon alanlarının kentte dengeli dağılmadığını belirtmişlerdir. Ayrıca, işçi ile akademisyen, doktor ve avukat vb. mesleğe sahip olanlar arasında birçok hususta önemli farklılıklar olduğu görülmektedir. İşçilerin yaptıkları iş ve elde ettikleri gelir göz önüne alındığında bu farklılıklar anlamlıdır.

Tablo 9- Meslek ve Rekreasyon Alanları İlişsisi

\begin{tabular}{|l|c|c|c|c|c|c|c|c|c|}
\hline & \multicolumn{7}{|c|}{ Meslek (\%) } \\
\cline { 2 - 9 } & $\begin{array}{c}\text { Ev } \\
\text { hanımı }\end{array}$ & Öğrenci & Emekli & Esnaf & $\begin{array}{c}\text { Akademisyen } \\
\text { Doktor, } \\
\text { Avukat vb. }\end{array}$ & Yönetici & $\begin{array}{c}\text { Büro } \\
\text { elemanı/ } \\
\text { Memur }\end{array}$ & İşci & p \\
\hline $\begin{array}{l}\text { Açık spor } \\
\text { alanları yeterlidir }\end{array}$ & 52.6 & 50.0 & 81.8 & 60.0 & 69.4 & 48.1 & 58.7 & 50.7 & - \\
\hline $\begin{array}{l}\text { Kapalı spor } \\
\text { alanları yeterlidir }\end{array}$ & 63.2 & 68.2 & 90.0 & 70.0 & 69.4 & 55.6 & 62.0 & 56.3 & - \\
\hline $\begin{array}{l}\text { Sahildeki } \\
\text { yürüyüş ve } \\
\text { bisiklet yolları } \\
\text { ayrılmalıdır }\end{array}$ & - & - & - & 30.0 & 5.6 & - & 4.8 & 6.9 & - \\
\hline $\begin{array}{l}\text { Kent merkezinde } \\
\text { yeterince park }\end{array}$ & 63.2 & 50.0 & 72.7 & 90.0 & 77.8 & 74.1 & 70.1 & 61.4 & - \\
\hline
\end{tabular}




\begin{tabular}{|l|c|c|c|c|c|c|c|c|c|} 
vardır & & & & & & & & & \\
\hline $\begin{array}{l}\text { Kent } \\
\text { merkezindeki } \\
\text { yeşil alan miktar } \\
\text { yeterlidir }\end{array}$ & 57.9 & 77.3 & 81.8 & 80.0 & 81.9 & 77.8 & 63.3 & 50.0 & - \\
\hline $\begin{array}{l}\text { Kültür ve sanat } \\
\text { merkezleri } \\
\text { yeterlidir }\end{array}$ & 36.8 & 63.6 & 72.7 & 70.0 & 65.3 & 55.6 & 55.8 & 41.7 & - \\
\hline $\begin{array}{l}\text { Kentte yeterince } \\
\text { tiyatro ve sinema } \\
\text { vardır }\end{array}$ & 42.1 & 81.8 & 72.7 & 80.0 & 56.9 & 40.7 & 57.8 & 47.2 & - \\
\hline $\begin{array}{l}\text { Eğlence } \\
\text { mekanları (disko, } \\
\text { türkü bar vb.) } \\
\text { yeterlidir }\end{array}$ & 21.1 & 59.1 & 36.4 & 60.0 & 33.3 & 25.9 & 33.7 & 51.4 & - \\
\hline $\begin{array}{l}\text { Mesire alanları } \\
\text { yeterlidir }\end{array}$ & 42.1 & 36.4 & 54.5 & 80.0 & 61.1 & 59.3 & 57.2 & 51.4 & - \\
\hline $\begin{array}{l}\text { Rekreatif alanlar } \\
\text { engellilerin } \\
\text { kullanımına } \\
\text { uygundur }\end{array}$ & 57.9 & 81.8 & 81.8 & 100.0 & 84.7 & 74.1 & 77.8 & 66.2 & - \\
\hline $\begin{array}{l}\text { Sahilde zaman } \\
\text { geçirmek için } \\
\text { mekanlar-aktivite } \\
\text { alanları yeterlidir }\end{array}$ & 47.4 & 59.1 & 63.6 & 70.0 & 68.1 & 70.4 & 62.0 & 48.6 & - \\
\hline $\begin{array}{l}\text { Kentin büyük bir } \\
\text { kütüphaneye } \\
\text { ihtiyacı vardır }\end{array}$ & 21.1 & - & 9.1 & - & 4.2 & 11.1 & 18.6 & 6.9 & - \\
\hline $\begin{array}{l}\text { Kentin gençlik } \\
\text { merkezlerine } \\
\text { ihtiyacı vardır }\end{array}$ & 10.5 & - & 9.1 & - & 2.8 & - & 6.6 & 4.2 & - \\
\hline $\begin{array}{l}\text { Yayalara özel } \\
\text { yeni caddeler } \\
\text { oluşturulmalıdır }\end{array}$ & 15.8 & - & - & 10.0 & 1.4 & - & 8.4 & 1.4 & - \\
\hline $\begin{array}{l}\text { Rekreasyon } \\
\text { alanları kentte } \\
\text { dengeli } \\
\text { dağılmıştır }\end{array}$ & 63.2 & 50.0 & 81.8 & 70.0 & 80.6 & 59.3 & 65.3 & 59.2 & - \\
\hline
\end{tabular}

\subsubsection{Memleket ve Rekreasyon}

Memleket ve rekreasyon alanları arasındaki ilişki Tablo 10'da görülmektedir. Bütün hususlarda ki kare analizi yapılmış fakat anlamlı ilişki bulunamamıştır. Bulgular oransal eğilimler üzerinden incelendiğinde, Ordulu olsun ya da olmasın katılımcıların hemen hemen \% 60'dan fazlası kentteki açık ve kapalı spor alanlarının, yarısından daha fazlası ise kültür ve sanat merkezleri ile tiyatro ve sinemanın yeterli olmadığını 
belirtmişlerdir. Araştırmaya katılanların \% 95'den daha fazlası memleketi fark etmeksizin sahildeki yürüyüş ve bisiklet yollarının ayrılması gerektiğini, gençlik merkezlerine ihtiyacı olduğunu ve yaylara özel yeni caddeler oluşturulması gerektiğini belirtmişlerdir. Ordulu olmayanlar kentin daha fazla parka, yeşil alana, sahilde mekanaktivite alanına ve büyük bir kütüphaneye ihtiyacı olduğunu belirtirken, Ordulu olanlar ise daha fazla mesire alanı ve eğlence mekanı olması gerektiğini belirtmişlerdir. Rekreatif alanların engellilere uygun olmadığını düşünenlerin oranı Ordulu olanlarda \% 74 iken, Ordulu olmayanlarda \% 82'dir.

Tablo 10- Memleket ve Rekreasyon Alanları İlişkisi

\begin{tabular}{|l|c|c|c|}
\hline \multirow{2}{*}{} & \multicolumn{2}{|c|}{ Memleket (\%) } \\
\cline { 2 - 4 } & Ordulu Olanlar & Ordulu Olmayanlar & p \\
\hline Açık spor alanları yeterlidir & 55.7 & 60.0 & 0.267 \\
\hline Kapalı spor alanları yeterlidir & 64.3 & 61.6 & 0.590 \\
\hline Sahildeki yürüyüş ve bisiklet yolları ayrılmalıdır & 5.5 & 4.1 & 0.832 \\
\hline Kent merkezinde yeterince park vardır & 66.7 & 74.0 & 0.264 \\
\hline Kent merkezindeki yeşil alan miktarı yeterlidir & 64.4 & 70.5 & 0.397 \\
\hline Kültür ve sanat merkezleri yeterlidir & 56.0 & 54.1 & 0.887 \\
\hline Kentte yeterince tiyatro ve sinema vardır & 54.9 & 58.2 & 0.668 \\
\hline Eğlence mekanları (disko, türkü bar vb.) yeterlidir & 39.1 & 35.6 & 0.522 \\
\hline Mesire alanları yeterlidir & 56.9 & 53.4 & 0.713 \\
\hline Rekreatif alanlar engellilerin kullanımına uygundur & 73.5 & 82.2 & 0.120 \\
\hline $\begin{array}{l}\text { Sahilde zaman geçirmek için mekanlar-aktivite } \\
\text { alanları yeterlidir }\end{array}$ & 57.3 & 66.4 & 0.107 \\
\hline Kentin büyük bir kütüphaneye ihtiyacı vardır & 14.2 & 7.5 & 0.139 \\
\hline Kentin gençlik merkezlerine ihtiyacı vardır & 5.9 & 2.7 & 0.278 \\
\hline Yayalara özel yeni caddeler oluşturulmalıdır & 6.3 & 2.7 & 0.053 \\
\hline Rekreasyon alanları kentte dengeli dağılmıştır & 64.8 & 68.5 & 0.748 \\
\hline
\end{tabular}

\subsubsection{Büyükşehir Deneyimi ve Rekreasyon}

Büyükşehirde yaşama ve rekreasyon alanları arasındaki ilişki Tablo 11'de görülmektedir. Büyükşehirde yaşama ile açık spor alanları yeterlidir, kültür ve sanat eserleri yeterlidir ve rekreasyon alanları kentte dengeli dağılmıştır arasında anlamlı ilişki bulunmuştur. Buna göre, büyükşehirde yaşayanların \% 65'i açık spor alanlarının yeterli olmadığını belirtmişlerdir. Günümüzde büyükşsehirlerin spor alanında daha fazla 
imkan sunduğu söylenebilir. Aynı şekilde, büyükşehirde yaşayanların \% 60’1 kentte kültür ve sanat merkezlerinin yeterli olmadığını düşünmektedir. $\mathrm{Bu} \quad$ durum spor alanlarında olduğu gibi, kültür ve sanat merkezleri konusunda da büyükşehirlerin daha fazla imkan sunmasıyla açıklanabilir. Bir diğer açıdan büyükşehirde yaşayan katılımcıların \% 71'i kentte rekreasyon alanlarının dengeli dağılmadığını belirtmişlerdir. Diğer hususlarda ki kare analizi yapılamamış veya anlamlı ilişki bulunamamıştır. Ancak oransal eğilimler üzerinden sonuçları değerlendirdiğimizde, katılımcılardan büyükşehirde yaşayanların \% 68'i kapalı spor alanlarının, \% 72'si kent merkezindeki yeşil alan miktarının, \% 41'i eğlence mekanlarının, \% 60’1 mesire alanlarının yeterli olmadığını belirtmişlerdir. Bütün bu hususlar, daha önce büyükşehirde yaşamış olan bireylerin bu alanlarda daha fazla seçeneği olduğunu göstermektedir. Katılımcılardan büyükşehirde yaşayanların \% 82'si rekreatif alanların engellilerin kullanımına uygun olmadığını düşünmektedir. Ayrıca, katılımcıların hemen hemen \% 90'dan daha fazlası büyükşehir deneyimi fark etmeksizin, sahildeki yürüyüş ve bisiklet yollarının ayrılması gerektiğini, kentin büyük bir kütüphaneye ve gençlik merkezlerine ihtiyacı olduğunu ve yaylara özel yeni caddeler oluşturulması gerektiğini belirtmişlerdir.

Tablo 11- Büyükşehirde Yaşama ve Rekreasyon Alanları İlişkisi

\begin{tabular}{|l|c|c|c|}
\hline \multirow{2}{*}{} & \multicolumn{2}{|c|}{ Büyükşehirde Yaşama (\%) } \\
\cline { 2 - 4 } & $\begin{array}{c}\text { Büyükşehirde } \\
\text { Yaşayanlar }\end{array}$ & $\begin{array}{c}\text { Büyükşehirde } \\
\text { Yaşamayanlar }\end{array}$ & p \\
\hline Açık spor alanları yeterlidir & 64.6 & 47.8 & $\mathbf{0 . 0 4 9}$ \\
\hline Kapalı spor alanları yeterlidir & 67.8 & 56.5 & 0.084 \\
\hline $\begin{array}{l}\text { Sahildeki yürüyüş ve bisiklet yolları } \\
\text { ayrılmalıdır }\end{array}$ & 5.4 & 4.3 & - \\
\hline Kent merkezinde yeterince park vardır & 73.3 & 76.6 & 0.266 \\
\hline $\begin{array}{l}\text { Kent merkezindeki yeşil alan miktarı } \\
\text { yeterlidir }\end{array}$ & 72.0 & 61.7 & 0.177 \\
\hline Kültür ve sanat merkezleri yeterlidir & 60.2 & 46.8 & $\mathbf{0 . 0 4 2}$ \\
\hline Kentte yeterince tiyatro ve sinema vardır & 58.0 & 61.7 & 0.728 \\
\hline $\begin{array}{l}\text { Eğlence mekanları (disko, türkü bar vb.) } \\
\text { yeterlidir }\end{array}$ & 40.5 & 31.9 & 0.317 \\
\hline Mesire alanları yeterlidir & 60.1 & 46.8 & 0.157 \\
\hline $\begin{array}{l}\text { Rekreatif alanlar engellilerin kullanımına } \\
\text { uygundur }\end{array}$ & 82.3 & 70.2 & 0.142 \\
\hline $\begin{array}{l}\text { Sahilde zaman geçirmek için mekanlar- } \\
\text { aktivite alanları yeterlidir }\end{array}$ & 65.3 & 66.0 & 0.967 \\
\hline
\end{tabular}




\begin{tabular}{|l|c|c|c|} 
Kentin büyük bir kütüphaneye ihtiyacı vardır & 13.6 & 4.3 & 0.169 \\
\hline Kentin gençlik merkezlerine ihtiyacı vardır & 4.9 & 4.3 & - \\
\hline Yayalara özel yeni caddeler oluşturulmalıdır & 7.0 & 2.2 & - \\
\hline Rekreasyon alanları kentte dengeli dağılmışır & 71.2 & 52.2 & $\mathbf{0 . 0 3 3}$ \\
\hline
\end{tabular}

\section{Tartışma ve Sonuç}

Büyükşehir statüsüne yeni kavuşmuş bir şehir olarak Ordu, Karadeniz'in doğal güzellikleri ile öne çıkan bir şehridir. Kentleşme deneyimi görece daha yeni olan bir kent olarak, çözüme kavuşturması gereken birçok problemi bulunmaktadır. Bunlar arasında, trafik, ulaşım, altyapı/üstyapı, rekreasyonel faaliyetler ve mekanlar en önemlileridir.

$\mathrm{Bu}$ çalışmada Ordu kentinde yaşayan insanların serbest zaman etkinlikleri incelenmiş ve çeşitli rekreasyonel alanlar hakkındaki görüşleri ortaya çıkarılmaya çalışılmıştır. Bir diğer ifadeyle, kentin rekreasyonel faaliyetler ve mekanlar açısından durumu analiz edilmeye çalışılmıştır.

Katılımcıların, her zaman ve sıklıkla şeklinde verdikleri cevaplar birlikte düşünüldüğünde, \% 41'inin alışveriş yaparak, \% 47'sinin kitap, gazete okuyarak, \% 55'inin müzik dinleyerek ve \% 67'sinin internette gezerek serbest zamanlarını değerlendirdikleri görülmektedir. Yukarıdaki faaliyetler genellikle kapalı mekanlarda yapılan faaliyetler olması, kentin açık mekanlar ya da faaliyetler konusunda sınırlı imkanlara sahip olduğu söylenebilir. Diğer taraftan, nadiren ve hiçbir zaman seçenekleri birlikte düşünüldüğünde ise, katılımcıların \% 47'sinin tatile, \% 57'sinin kafeye, \% 62'sinin sinemaya, \% 67'sinin çeşitli kurslara, \% 72'sinin tiyatroya, \% 77'sinin konsere ve \% 84'ünün kahveye nadiren gittiği ya da hiçbir zaman gitmediği görülmektedir. Katılımcıların neredeyse üçte birinin sinema, çeşitli kurslar, tiyatro ve konser gibi serbest zaman etkinliklerine katılmiyor olması da, kentin bu anlamda sunduğu imkanların yetersizliğiyle açıklanabilir. Ayrıca katılımcıların sadece \% 24'ünün spor yapması da bu çerçevede açıklanabilir. Neticede bütün bu etkinlikler göz önüne alındığında kentin sosyal yaşam noktasında önemli eksiklikleri olduğu görülmektedir. 
Bu bağlamda bulgularımız, TÜİK tarafindan 2015 yılında yapılan İllerde Yaşam Endeksi araştırması sonuçlarıyla paralellik taşımaktadır. Buna göre, sinema ve tiyatro seyirci sayısı (yüz kişide) 29,8, bin kişiye düşen alışveriş merkezi alanı $\left(\mathrm{m}^{2}\right) 10.8$ ve sosyal hayatından memnun olanların oranının \% 45 olması ve Ordu'nun sosyal yaşam sıralamasında 69. sirada olması da (TÜİK, 2015) kentin rekreasyon alanları veya faaliyetleri açısından yetersizliğini ortaya koymaktadır.

Katılımcıların \% 61'inin rekreasyon alanlarını düzenli kullanmamaları, \% 86'sının serbest zamanını evde geçirmesi ve özellikle spor tesisleri ve kültür-sanat merkezlerinde harcanan zamanın az olması (\% 16) ve rekreatif faaliyet ve alanlarla ilgili sorunların \% 32 ile üçüncü sırada yer alması kentin bu noktada yetersizliğini ortaya koymakla birlikte, TÜİK (2015) sonuçlarıyla da benzerlik taşıdığını göstermektedir.

Cinsiyet ve rekreasyon alanları arasındaki ilişki de, her iki cinsiyet açısından kendi içinde birtakım farklılıklar olsa da, rekreasyon alanları noktasında kentin önemli eksiklikleri olduğu görülmektedir. Cinsiyet fark etmeksizin katılımcıların \% 50'sinden fazlası, açık spor alanlarını, kültür ve sanat merkezlerini, mesire alanlarını ve \% 60'dan fazlası ise kapalı spor alanlarını, parkları, yeşil alanları, sahildeki mekan-aktivite alanlarını yeterli görmemektedir. Diğer taraftan, \% 90'dan daha fazlası ise sahildeki bisiklet ve yürüyüş yollarının ayrılması gerektiğini, kentin gençlik merkezlerine ve yayalara özel yeni caddelere ve aynı şekilde katılımcıların yaklaşık \% 90’ı kentin büyük bir kütüphaneye ihtiyacı olduğunu belirtmişlerdir. Ancak, katılımcıların \% 60'dan az fazlası, eğlence mekanlarının yeterli olduğunu ifade etmişlerdir. Sonuçları bir bütün olarak ele aldığımızda, kent cinsiyet fark etmeksizin ihtiyaçları karşılayamadığı görülmektedir.

Yaş ile rekreasyon alanları arasındaki ilişki incelendiğinde, 25 yaşından 54 yaşına doğru, açık ve kapalı spor alanlarını, kent merkezindeki parkları ve yeşil alanları, kültür ve sanat merkezlerini ve mesire alanlarını yeterli görmeyenlerin oranının arttığı görülmektedir. Bu durum, insanların 25 yaşından sonra iş yaşamına girmeye başlaması, evlenmesi ve çocuk sahibi olması ve beraberinde özellikle yoğun iş temposu ve şehrin karmaşasından kurtulmak ve dinlenmek için, ister birey olarak isterse ailesiyle birlikte 
rekreatif faaliyetlere daha fazla ihtiyaç duymasıyla açıklanabilir. Katılımcıların yaş fark etmeksizin \% 90'dan daha fazlasının sahildeki bisiklet ve yürüyüş yollarının ayrılması gerektiğini, kentin büyük bir kütüphaneye, gençlik merkezlerine, yayalara özel yeni caddelere ihtiyacı olduğunu belirtmesi, bu konuda kentin önemli eksiklikleri olduğunu göstermesi açısından önemlidir. Ayrıca, gençlerde tiyatro ve sinemaya olan talep \% 76 iken, bu oran 55 ve üstü yaş grubunda \% 41'e düşmekte ve aynı şekilde eğlence mekanlarına daha çok ihtiyaç duyanların gençler olduğu (\% 54), tam tersi en az ihtiyaç duyanların ise yaşlıların olduğu (\% 12) görülmektedir. Bu noktada özellikle hayatlarının en hareketli ve aktif oldukları dönemde gençlerin enerjilerini, onlara faydalı olabilecek bu tür rekreatif alanlarda atmaları, onların olumsuz birtakım eylem ve davranışlara yönelmemeleri açısından da ayrıca önem taşımaktadır.

Eğitim ve rekreasyon alanları arasındaki ilişki incelendiğinde, kentteki yeşil alanların, kültür ve sanat merkezlerinin, sahildeki mekan ve aktivite alanlarının eğitim düzeyi arttıkça yeterli olmadığı görülmektedir. Özellikle kültür ve sanat merkezi gibi kültürel sermaye ile ilgili olan faaliyetlere olan talebin, eğitim düzeyi arttıkça artması anlamlıdır. Eğitim düzeyi fark etmeksizin katılımcıların \% 80'inden daha fazlası sahildeki yürüyüş ve bisiklet yollarının ayrılması gerektiğini, kentin büyük bir kütüphaneye ve gençlik merkezlerine ihtiyacı olduğunu ve yayalara özel yeni caddelerin oluşturulması gerektiğini belirtmişlerdir. Ayrıca eğitim düzeyi fark etmeksizin, katılımcıların hemen hemen dörtte üçü kent merkezinde yeterince park olmadığını ve \% 60'dan daha fazlasının ise kapalı spor alanlarının yeterli olmadığını ifade etmişlerdir.

Gelir ve rekreasyon alanları arasındaki ilişki incelendiğinde, katılımcıların \% 85 'inden daha fazlası gelir düzeyi fark etmeksizin, sahildeki yürüyüş ve bisiklet yollarının ayrılması gerektiğini, kentin büyük bir kütüphaneye ve gençlik merkezlerine ihtiyacı olduğunu ve yayalara özel yeni caddeler oluşturulması gerektiğini belirtmişlerdir. Eğitim düzeyi ve rekreasyon alanları ilişkisinde olduğu gibi, kent merkezindeki yeşil alan miktarının yeterli olmadığını düşünenlerin oranı, gelir düzeyi yükseldikçe artmaktadır. Rekreasyon alanlarının engellilerin kullanıma uygun olmadığını düşünenlerin oranı, gelir düzeyi yükseldikçe artmaktadır. Bu durum gelir 
düzeyi yükseldikçe engelliler ile ilgili bilgi ve bilinç düzeyinin arttığını göstermektedir. Aynı durum, rekreasyon alanları kentte dengeli dağılmıştır sorusunda da gözlenmektedir. Açık ve kapalı spor alanlarının yeterli olmadı̆̆ını daha çok gelir düzeyi 3001-5000 Ł arasında olanlar belirtmişlerdir. Bu durum, gelir düzeyi arttıkça insanların spor yapma oranı arttı̆̆ından. Mevcut spor tesislerini yetersiz görmesiyle açıklanabilir.

Meslek ve rekreasyon alanları arasındaki ilişki incelendiğinde, açık ve kapalı spor alanlarının yeterli olmadığını düşünenlerin daha çok emekliler olduğu görülmektedir. Bu durum emeklilerin emeklilik sonrası serbest zamanlarının artması ve bu zamanlarını değerlendirmek için çeşitli mekan ve aktiviteler aramasıyla açıklanabilir. Araştırmaya katılanların \% 80'den daha fazlası mesleği fark etmeksizin sahildeki yürüyüş ve bisiklet yollarının ayrılması gerektiğini, kentin büyük bir kütüphaneye ve gençlik merkezlerine ihtiyacı olduğunu ve yaylara özel yeni caddeler oluşturulması gerektiğini belirtmişlerdir. Diğer taraftan işçilerle, akademisyen, doktor, avukat vb. mesleğe sahip olanlar arasında birçok hususta önemli farkl1lıklar bulunmaktadır. Kentteki spor alanlarının, parkların, yeşil alanların, kültür ve sanat merkezlerinin, tiyatro ve sinemaların, mesire alanlarının ve sahildeki mekan-aktivite alanlarının yeterli olmadığını daha çok akademisyen, doktor, avukat vb. mesleğe sahip olanlar belirtmişlerdir. Kol emeği ile ve uzun süre çalışan işçinin hem serbest zamanı hem enerjisi hem de bu tür rekreatif faaliyetler için yeterli parası olmayacağından, dolayısıyla bu mekanların ya da faaliyetlerin varlığı ya da yokluğu işçi için bir anlam ifade etmeyecektir.

Memleket ve rekreasyon alanları arasındaki ilişki incelendiğinde, Ordulu olsun ya da olmasın katılımcıların hemen hemen \% 60'dan fazlası kentteki açık ve kapalı spor alanlarının, yarısından daha fazlası ise kültür ve sanat merkezleri ile tiyatro ve sinemanın yeterli olmadığını belirtmişlerdir. Araştırmaya katılanların \% 95'den daha fazlası memleketi fark etmeksizin sahildeki yürüyüş ve bisiklet yollarının ayrılması gerektiğini, gençlik merkezlerine ihtiyacı olduğunu ve yaylara özel yeni caddeler oluşturulması gerektiğini belirtmişlerdir. Ordulu olmayanlar kentin daha fazla parka, yeşil alana, sahilde mekan-aktivite alanına ve büyük bir kütüphaneye ihtiyacı olduğunu 
belirtirken, Ordulu olanlar ise daha fazla mesire alanı ve eğlence mekanı olması gerektiğini belirtmişlerdir. Rekreatif alanların engellilere uygun olmadığını düşünenlerin oranı Ordulu olanlarda \% 74 iken, Ordulu olmayanlarda \% 82'dir. Sonuçları genel olarak değerlendirdiğimizde, Ordulu olmayanlar birçok hususta (açık spor alanları, parklar, yeşil alanlar, tiyatro ve sinema, sahildeki mekan-aktivite alanları, engellilere uygunluk ve rekreasyon alanlarının dağılımı) kenti Ordululara kıyasla daha yetersiz görmektedir. Bu durum, kendi memleketlerinde veya daha önce yaşadıkları şehirde rekreatif faaliyetler ya da rekreasyon alanları noktasında daha fazla imkana sahip olmalarıyla açıklanablir. Ancak, hemen hemen bütün hususlarda kendi içindeki farklılıklara rağmen, katılımcılar kentin rekreasyon alanları noktasında önemli eksiklikleri olduğu belirtmişlerdir.

Büyükş̧ehirde yaşama ve rekreasyon alanları arasındaki incelendiğinde, büyükşsehirde yaşayanlar birçok hususta (açık ve kapalı spor alanları, yeşil alanlar, kültür ve sanat merkezleri, eğlence mekanları, mesire alanları, engellilere uygunluk ve rekreasyon alanlarının dağglımı) kenti yetersiz görmektedir. Ayrıca, kentin daha büyük bir kütüphaneye ihtiyacı olduğunu ve yayalara özel yeni caddeler oluşturulması gerektiğini belirtmişlerdir. Bu durum, büyükşehirlerin bu hususlarda daha fazla imkan sunmasıyla açıklanabilir. Ayrıca, katılımcıların hemen hemen \% 90'dan daha fazlası büyükşehir deneyimi fark etmeksizin, sahildeki yürüyüş ve bisiklet yollarının ayrılması gerektiğini ve gençlik merkezlerine ihtiyacı olduğunu belirtmişlerdir. Aynı şekilde, hemen hemen katılımcıların \% 60'dan daha fazlası, kentteki tiyatro ve sinema ile sahildeki mekan ve aktivite alanlarının, dörtte üçü ise kent merkezindeki parkların yeterli olmadığını belirtmişlerdir. Neticede, büyükşehir deneyimi fark etmeksizin kentin rekreasyon alanları konusunda önemli eksiklikleri olduğu çok açık bir şekilde görülmektedir.

Sonuç olarak, araştırma grubunun alışveriş yaparak, kitap, gazete okuyarak, müzik dinleyerek internette gezerek serbest zamanlarını değerlendirdikleri; rekreasyon alanlarını düzenli kullanmadıkları; serbest zamanlarını genellikle evde geçirdikleri ve rekreatif faaliyet ve alanlarla ilgili eksiklikleri önemli sorunlar arasında 
değerlendirdikleri görülmektedir. Ayrıca, yaş, cinsiyet, eğitim, gelir, meslek, memleket ve büyükşehir deneyimi ekseninde verilen cevaplar kendi içinde farklılıklar gösterse de genel olarak rekreasyon alanları konusunda kentte bir yetersizliğin olduğu tespit edilmiştir. Ancak, araştırmanın yapıldığı tarihten bu yana, sahildeki yaya ve bisiklet yollarının ayrılması, yayalara özel yeni caddeler oluşturulması, bazı spor tesisleri yapılması yönünde adımlar atıldığı ve alışveriş merkezi yapılması ile ilgili çalışmaların olduğu da görülmektedir. $\mathrm{Bu}$ adımlar, genel olarak rekreasyon alanları eksikliğini gidermese de önemli adımlar olduğunu ifade etmek gerekir. 


\section{KAYNAKÇA}

AKOVA, İsmet (2012). “Turizm Coğrafyası ve Planlama”, Turizm Coğrafyası, ed. Semra Günay, ss. 2-36, Eskişehir: Anadolu Üniversitesi Yayınları.

AKTEN, Sibel ve Atila GÜL (2014). “Korunan Doğal Alanlarda Ziyaretçilerin Olası Etki Düzeyleri Önlem ve Standartlarının Belirlenmesi (Gölcük Tabiat Park1 Örneği)", SDÜ Orman Fakültesi Dergisi, 15: 130-139.

ALTUNKASA, Mehmet Faruk (2013). Rekreasyonel Planlama Organizasyon, Adana: Çukurova Üniversitesi Ziraat Fakültesi Yayınları.

BRAUDEL, Fernand (2014). Uygarlıkların Grameri, çev. Mehmet Ali Kılıçbay, Ankara: İmge Kitapevi.

ÇİFTÇİ, Salih (2011). "Küreselleşmenin Türkiye'deki Kentler Üzerine Etkisi”, Bartın Üniversitesi İ.I.B.F. Dergisi, 2(3): 73-81. Yayınları.

DAVIS, Mike (2007). “Gecekondu Gezegeni”, çev. Gürol Koca, İstanbul: Metis

GIDDENS, Anthony ve Philip W. SUTTON (2016). Sosyoloji, 7. Bask1, İstanbul: Kırmızı Yayınları.

GÜL, Atila ve Volkan KÜÇÜK (2001). "Kentsel Açık-Yeşil Alanlar ve Isparta Kenti Örneğinde İrdelenmesi”, Süleyman Demirel Üniversitesi Orman Fakültesi Dergisi, 2: 27-48.

KARAKÜÇÜK, Suat (2001). Rekreasyon-Boş Zamanları Değerlendirme, 4. Bask1, Ankara: Gazi Kitapevi.

KAYA, Erol (2007). Kentleşme ve Kentlileşme, İstanbul: Okutan Yayıncılık.

KONAK, Nahide (2011). "Küresel Kentler Kuramı ve Araştırmaları", Kent Sosyolojisi, ed. Fatime Güneş, ss. 144-174, Eskişehir: Anadolu Üniversitesi Yayınları.

MANSUROĞLU, Sibel (2002). “Akdeniz Üniversitesi Öğrencilerinin Serbest Zaman Özellikleri ve Dış Mekan Rekreasyon Eğilimlerinin Belirlenmesi”, Akdeniz Üniversitesi Ziraat Fakültesi Dergisi, 15(2): 53-62.

MCLEAN, Daniel D., HURD, Amy R. \& Nancy Brattain ROGERS (2008). Kraus' Recreation and Leisure in Modern Society, Burlington: Jones and Bartlett Publishers.

ÖZER, İnan (2006). "Türkiye'de Kent, Kentleşme ve Kentsel Değişme", Dünden Bugüne Türkiye'nin Toplumsal Yapısı, ed. Mehmet Zencirkıran, ss. 269-299, Bursa: Dora Yayınları. Yayınları.

RITZER, George (2011). Küresel Dünya, çev. Melih Pekdemir, İstanbul: Ayrıntı

SERTER, Gencay (2013). "Şikago Okulu Kent Kuramı: Kentsel Ekolojik Kuram", Planlama, 23(2): 67-76. 
ŞİMŞEK, Derya Serbest ve Aslı Bayçın KORKUT (2009). "Kıyı Şeridi Rekreasyon Potansiyelinin Belirlenmesinde Bir Yöntem Uygulamas1: Tekirdağ Merkez İlçe Örneği”, Tekirdağ Ziraat Fakültesi Dergisi, 6(3): 315-327.

T.C. Çevre ve Şehircilik Bakanlığı (2015). Ordu İli 2015 Yılı Çevre Durum Raporu, Ordu: T.C. Ordu Valiliği Çevre ve Şehircilik İl Müdürlüğü.

TOLUNAY, Ahmet, ALKAN, Hasan ve Mehmet KORKMAZ (2004). "Isparta Tarihi Ayazmana Mesireliği'nin Açıkhava Rekreasyonu Açısından Kullanıcı Özellikleri”, Süleyman Demirel Üniversitesi, Fen Bilimleri Enstitüsü Dergisi, 8(1): 5970 .

TÜİK (2015). “İllerde Yaşam Endeksi 2015”, Erişim Tarihi: 04 Ağustos 2017, (http://www.tuik.gov.tr/PreHaberBultenleri. do?id=24561).

TÜİK (2016). Il ve Illçelere Göre Illillçe Merkezi, Belde/Köy Nüfusu ve Yıllık Nüfus Artış Hızı, Ankara: Türkiye İstatistik Kurumu, Adrese Dayalı Nüfus Kayıt Sistemi (ADNKS) Veri Tabanı.

YAHYAGİL, Mehmet (1998). "Kentlerin Kültürün Gelişimine Etkileri” Sosyoloji Konferanslarl, ss. 105-120, İstanbul: İ.Ü.İ.F.

YEŞIL, Murat ve Murat YÜKSEL (2016). “Ordu Kenti Örneğinde Kentlilik Bilinci”. PARADOKS Ekonomi, Sosyoloji ve Politika Dergisi, 11: 43-65. 